\title{
THE CRISIS OF LIBERAL DEMOCRACY AND THE NATIONALIST COUNTER-PROJECT. THE PROBLEM OF THE RELATIONALITY BETWEEN AN INDIVIDUAL, THE SOCIETY AND THE AUTHORITY
}

\author{
Krzysztof CEBUL, PhD hab. \\ Institute of Political Science, Faculty of Historical and Social Sciences \\ Cardinal Stefan Wyszynski University in Warsaw, Poland \\ krzysztofcebul@wp.pl
}

\begin{abstract}
At the root of the article, there is an argument on the crisis of liberal democracy, which manifests itself in the atomisation of society, exacerbated by consumerism(among other things), and consequently, withdrawal of individuals from the public space, as well as an unwitting resignation from, for example, the rights of scrutiny over authority. It needs to be noticed that the above diagnosis may stem both from the concern about liberal democracy, the belief that there is no alternative to it, but it may also be derived from the conviction that it is necessary to reject liberal democracy and replace it with some other, allegedly better project. One of such counter-projects is nationalism. Every project of social organization, including liberal democracy, just like nationalism, adopts a certain catalogue of obligations or expectations towards individuals, citizens, members of the nation (the obligatory aspect). The aim of this paper is to analyze the connections between an individual, the society and the state, that is the scope of relationships determining certain obligatory aspects, namely the contents of obligations corresponding to the requirements of liberal democracy efficiency and the contents of obligations necessary to preserve the coherence of the nationalist counter-project, as well as specific costs (some kinds of hardships) necessary to achieve the efficiency of each of these systems. The subjects of reference in the text, despite the generalized character of some of the arguments mentioned in the text, are the Polish society and state.
\end{abstract}

Keywords: crisis of liberal democracy, liberal democracy, nationalism, individual, society, authority, state, atomisation, community, nation, civic duties, civic preparation.

\section{Introduction}

The provenance of the thesis claiming that liberal democracy is in crisis may have two sources. Firstly, this diagnosis may stem from the concern about liberal democracy, acknowledged, for a reason, to be the best system invented by people (in spite of its various deficits), in which 
individuals are given significant space of freedom while they are subjected to some slight, not particularly oppressive and generally predictable scope of constraint (compared to other social inventions in which people experienced or are still experiencing oppression in a greater and considerably less predictable scope). Secondly, its criticism may be due to the belief that liberal democracy has some genetic flaws, leading, as some believe, to the breaking down of the society and the destruction of the community. On one hand thus we basically have the belief that there is no alternative to liberal democracy which, after all, must be taken care of. On the other hand, we have a categorical demand that we reject liberal democracy and the consecutive demand that it be replaced with another project. One of such counter-projects is nationalism.

The fundamental problem for both of these directions boils down to the determination of the obligatory aspect, that is to the determination of obligations or expectations towards individuals, citizens, members of the nation. Although social inventions undoubtedly reflect human nature, they require, due to the vagueness of this category, a certain way of behavior, not necessarily an obvious one and not particularly comfortable one. They require that we follow certain rules determining the efficiency of a given system.

The aim of this article is to analyze the connections between an individual, the society and the state, that is the scopes of the title relationship determining obligatory aspects and thus the content of obligations corresponding to the requirements of the efficiency of liberal democracy and the content of obligations necessary to maintain the coherence of the nationalist counterproject, as well as specific costs (hardships) necessary to achieve the efficiency of each of these systems.

The whole political sphere is permeated and determined by planned and organized efforts made by people to in and hold power (Ryszka, 1984, p. 18). In every organizational form of the society we can distinguish power and many dependencies related to it and generated by it. Power permeates social life, constituting in fact a multi-subject social relationship, shaped by the authority's power of influence (Murawski, 1993, pp. 34-35). The variable determining the activity of the power subject is the field and the scope. This term covers a collection of various human activities which depend directly on the power or should depend on it if a person is in the scope of the power influence and the authority possesses relevant force. Each element of this collection reflects the relationship between power and every dependent subject (Ryszka, 1984, pp. 30-31). In the case of the term relationality, it is a kind of a relationship (in the formalised and non-formalised 
dimensions combined), i.e. the bonds connecting: 1) the individual (citizen) with 2) society and also with 3) authority which, according to Rudolf Smend, create the national space (Kaczorowski, 2005 , p. 231). These ties determine the level of individuals' motivation to be loyal, to act and, above all, they determine the scope of distinctive responsibility (care, reflection) in the public sphere - they determine the degree of identification of an individual, a citizen with the state, i.e. as Paweł Kaczorowski called it - the ethical substance of state life (Kaczorowski, 2005, p. 236), i.e. both materialised and non-materialised imperatives. At this point, it should also be indicated, that the main point of reference in the text will be the contemporary Polish society and state, despite the references to significantly generalized images of the individual, the society and the state.

The text by no means claims to be an in-depth and complete analysis of the subject issue as it is impossible to conduct a careful synthesis of liberal democracy and nationalism on several pages. Therefore, faced with their complexity, the author cannot present the issue of relationality at length. The aim of this paper is to draw the reader's attention to the obligation aspect outlined in the above-described relationality. The obligation situation reproduces a dilemma which, it seems, particularly a contemporary individual in their existential dimension. And even more so, or above all, when the individual does not notice that. Undoubtedly, the renaissance of the nationalist narration, observed also now in the public discourse, makes us inclined to reflect on this area, too. However, we should emphasize that in spite of the thesis on the crisis of liberal democracy, so visible in the text, the author treats the nationalism only as one of many ideas for organizing social life.

\section{The network of concepts}

Before carrying out the tasks outlined above, it is necessary to define the scope of meaning of the terms: liberal democracy and nationalism. Due to their ambiguity, defining these concepts creates some fairly significant problems. We may find some reasonably coherent concepts and assumptions here, but at the same time we are also entering the area of political practice, where these projects come to life. As a consequence, things which are identified at both levels in the same categories, usually significantly differ from each other. An attempt to reduce the observed diversity with the use of one term, in consequence, not only introduces considerable confusion, but also often constitutes a rather simple explanation that the experienced consequences of the implementation of one or another idea, is not what the creator had in mind when making his 
project. Jerzy Szacki once aptly (as it seems) expressed the important reason for this gap, by writing that every ideology is applied in a certain historical context and by "taking root" in specific social circumstances, undergoes greater or lesser changes (Szacki, 1991, p. 232).

When writing about liberal democracy, it is necessary to note that the essence of the modern democratic revolution, as Tomasz Żyro emphasizes, is a clash of the ideas of equality and freedom. Liberal democracy seems to be organised primarily by formal principles. The state and government are instruments created by the people for their own purposes. Thus, for example, the people delegate their representatives to rule, and all matters are settled by the will of the majority, which is, in turn, limited by minority rights, while the condition for a democracy described in this way is a strict rule of law, through which the principle of total equality is implemented, which is only the foundation for perfect freedom. At the same time, the prerequisite for safeguarding this freedom is the participation of citizens, and the guarantee of free choice is the freedom of speech and expression of opinion. The legal order, but also the procedures for preventing decisions from being made, and ultimately the right to civil disobedience, are the limits to the decisions of the political authority. The relations between the individual, the society and authority are determined by a triad, which comprises of: 1) standards of moderation, 2) the art of compromise and 3) transparency of political decisions, while its shape is determined by openness to change (Żyro, 2004, pp. 205-208).

As Jacob Leib Talmon argues, liberal democrats themselves are deeply convinced that if people and societies are not subject to oppression, they can reach the state of perfect harmony through experimental means (Talmon, 1992, p. 68). It is often pointed out that liberal democracy has not been called this way, because it appeals only to liberals and nobody else (Szacki, 1994, p. 25). It is therefore not unreasonable that liberal democracy claims to be a universal system. However, it also means that one does not have to be a liberal to live in a liberal democracy. The same applies to nation states, which were not and are not intended only for nationalists. In general, both as ideas and as real beings, they are a consequence of social processes and the experience of the societies that have to live in them.

As J. L. Talmon writes, political systems are nothing more than pragmatic inventions of human creativity and spontaneity. Political forms are therefore secondary to the social spacecreating, rational and sensible individuals. Liberal democracy, therefore, means acceptance of the diversity of individual levels and collective aspirations that go completely beyond the sphere of politics (Talmon, 1992, p. 67). It can be observed here that in the perspective offered by liberal 
democracy the political sphere is somehow narrowed. This exclusion serves the minimization of conflict situations, as it moves certain fields outside the sphere of politics, thus making political negotiations unnecessary. From the perspective of the efficiency of the system, this treatment seems beneficial (although only seemingly) since it considerably decreases the scope of responsibility. However, it simultaneously evokes the rather untrue conviction that some fields are independent of the sphere of politics. Moreover, the weakening of the possibility of conflicts takes place in liberal democracy via guaranteeing individuals participation in politics and the possibility of taking part in competition for power, while guaranteeing everyone who is not interested that they will not have to take part in this competition. Through this action the actual level of participation becomes insignificant and democracy is guaranteed only through the right to participate (Etzioni-Halevy, 2005, p. 119). Therefore, looking at the contemporary Polish state from the perspective of this approach, it is worth paying attention to certain deficiencies and related dysfunctions conditioned by specific experiences. Remembering what John Gray points out, that we practice historically random and peculiar forms of life that we inherit or adopt (Gray, 2001b, p. 49), and therefore, in relation to the sphere of an imperative aspect, we use those models of moral and political life which are available to us (Gray, 2001b, p. 47).

The ideological foundations of Polish nationalism were laid out by Roman Dmowski ${ }^{2}$ in the Thoughts of a modern Pole [Myśli nowoczesnego Polaka] (Wapiński, 1989, pp. 99-100), although it should also be remembered that the National Democratic camp was only a part of a rather diverse nationalist trend (see on this subject: Wapiński, 1980; Rudnicki, 1985; Majchrowski, 1986; Grott, 2014). The issue of continuation and references to his heritage remains complex and sometimes quite problematic (see on this subject: Tomasiewicz, 2003).

Taking into account the fact that the nations of Western Europe formed in the process of ideological confrontation with other communities, their modernization power stemmed from their willingness to keep up with others or even to exceed them, and this goal motivated the societies and encouraged them to sacrifices (Radzik, 1997, p. 89). Thus the program written down by Roman Dmowski was nothing new to German, English or French people. For the Poles at that time, however, it was a novelty (Studnicki, 2001, p. 132). These different experiences determining the

\footnotetext{
2 Roman Stanisław Dmowski (1864-1939) - Polish politician, political writer and ideologist of National Democracy, co-creator of the National Democratic Party, member of the Russian Duma (legislative assembly), Poland's delegate to the peace conference in Paris, in the Second Republic of Poland he was minister of foreign affairs, founder of the Camp of Great Poland and the National Party.
} 
specific development of Poland were due to the fact that Central and Eastern Europe in which Poland lies, was shaped as a result of historical experiences different to those of Western Europe. Its civilization is younger and its economy weaker. We can also see the differences in the "intuitively" adopted hierarchy of values, which is less concentrated on material goods (Cywiński, 1985, pp. 15-16). Poles were the only nation which not only lost its own state, but was partitioned among three invaders. For a very long time this situation could not be changed. One could add here the Nazi and the Stalinist occupation and, to some extent, a period of nearly half a century when ur country was dependent on the Soviet Union. It should also be mentioned that the nationalistic awakening in Poland in 1989, as well as in other post-communist countries, manifested in regaining the ability of self-determination, was soon subjected to hard ordeal which, in the internal dimension, consisted in learning the positive role of compromise, and externally, due to the dominant potential of foreign partners and the need to seek their support, the acceptance of the necessity to adjust. In both dimensions it was also important to learn to reduce one's expectations.

While looking for a definition of nationalism, it is worth noting from Joanna Kurczewska, that the consequence of nationalism, which grows out of extreme cognitive and emotional monocentrism is a "system of culture of the nationalized individual" concentrated on its own nation, whose differentiating power divides social space into "foreign social worlds", where one of them is always better than the other (Kurczewska, 1988, p. 69). This explanation, however, must be considered insufficient, because the genesis of nationalism cannot be ignored when searching for its essence. It is worth to mention here the observation of Leszek Kołakowski, who, when writing about the natural resistance of human institutions created spontaneously against democracy as a planned form, stated that a nation as an ethnic being, like every natural creation, carries in itself a specific form of self-preservation drive. It simply wants to last and wants to be strong. In almost all countries, says L. Kołakowski, there are, after all, extreme nationalist movements and although they may not express the proper sense of national being, they are not, however, a pathology but a true product of the nation in the moments when it feels threatened, whether by democracy or by other circumstances (Kołakowski, 1999, pp. 72-76). At the same time, regardless of the claims made by the nationalists themselves, it seems necessary to make a stipulation here that the nation, as Antonina Kłoskowska points out, is not, in reality, a community so "full", 
"uniform" and "continuous" (Kłoskowska, 1997, p. 73). Besides, national awareness is always a function of confrontation with some different awareness (Kwaśniewski, 1996, p. 76).

The crisis of modern liberal democracy in the face of nationalism and political liberalism

A citizen in the modern liberal democratic state does not, in principle, co-create the public space. He neither concludes the agreement, nor renegotiates the contract. He seems to be forced into a system that surrounds him with not necessarily understandable orders and prohibitions, but requires his obedience. Therefore, it can be assumed that liberal democracy is in crisis, but it can also be said quite legitimately that what sustains liberal democracy is paradoxically a lack of interest in it, on the part of the society and, ultimately, a rather passive submission to sometimes even unreasonable rules. Societies do not show any particular concern for this system, and yet, as if in spite of these tendencies, liberal democracy continues to exist for the time being. Quite contrary to the fundamental assumption that in a democracy the collective order is created by all those, who at the same time are submitted to it (Kelsen, 1936, pp. 20-21), and therefore the most important part of a democratic political system does not fall within the constitution, but is located in experience and the notions resulting from it (Wasiutyński, 1986, p. 54). Democracy, writes T. Żyro, like no other political system, testifies to ideocracy, i.e. to the unprecedented reign of ideas in the public discourse (Żyro, 2004, p. 205). However, if democracy has to irrevocably fail in the absence of such a suitable environment (Baszkiewicz, 2002, p. 276), then perhaps the system which we live in, is only mistakenly described as a liberal democracy?

Starting from the formal and informal dimensions of democracy, it must be assumed that the first level is sufficient for the system to last, although it is highly questionable, whether it is still justified to call it a liberal democracy. If this is the case, the citizens must have a guaranteed possibility of choice, but they must also have the capacity to make choices. This ability, which is expressed in knowledge, is essential for exercising control. So, whoever wants to be left alone and not to be tormented by politics, this way puts his will in the hands of others (Crick, 2004, p. 20). Yet, in spite of this, it turns out that in the modern democracy subjective relations occur only, as Adam Karpiński believes, on a formal and logical level. Perhaps liberal democracy is necessarily formal and, thus, limited to one side of social life, because the other side of social life escapes the framework of formal order (Karpiński, 2001, p. 245). Such a diagnosis seems quite probable, if 
one adopts A. Karpiński's argument that in the consumer society, the human spirit is "seduced" by biologicality, and in fact by the owners of the capital (Karpiński, 2001, p. 247). In Poland, for example, the structure of a system which is under development, the structure resulting from certain circumstances, turned out to be quite sufficient in the dimension necessary for its endurance. At the same time, however, it is worth noting that it was the reception of liberal ideas in Poland after 1989, that constituted in the past and still constitutes an extremely important factor in the development of democratic awareness. And it happened despite the fact, that liberalism was treated "selectively" and "instrumentally" in Poland. (Krasnodębski, 2003, p. 273).

Looking for an answer to the question about the relationality of nationalism and liberal democracy (or, in fact, looking for the roots of tension between them), one could say that the matter is quite obvious and the opposition of these two projects is inevitable. Since nationalism manifests concern for the collective; not every collective, however, but only for this particular national collective, while liberalism defends individuals against the pressure from not only all collectives, but also from other individuals, from the perspective of liberal democracy, nationalism must simply be considered a threat to equality and, as a consequence, to the freedom of individuals. Adoption of this approach is usually facilitated by those who consider themselves nationalists, without hiding the fact that they reject liberal democracy (although not necessarily all those who are referred to as nationalists).

Nationalists, however, do not seem to notice that liberal democracy does not necessarily have to be just what they are currently observing and what they often, quite rightly so, do not particularly like. Their counter-project, through a rather strongly articulated argument about the need to reject liberal democracy, seems to be its opposite and, as a result, a threat to the values to which the general public is rather accustomed (which will be discussed further). Although this does not mean at all that the general public is aware of their functions and, above all, that these values require constant efforts to uphold and confirm their relevance (validity). However, this is not at all an accusation against the abovementioned general public. If anything, one could say that we have to live in the conditions that make it quite difficult to care for our own consciousness perceived as the independence of courts, because, as T. Żyro writes, in the situation of "a deep atomisation of potential voters, due to torn or even broken civil bonds, the voter is dependent on manipulation and psychomanipulation provided by the instruments of political marketing". In addition, this atomized citizen is subject to "a pressure from an organized electoral machine which 
political parties nowadays are" (Żyro, 2013, p. 79). Finally, as Stanisław Filipowicz observes, the dominance of television, signalling the return of the "pictographic script" makes the word redundant. The media are an "anthropogenic" tool, which is a tool of authority, where everything that is presented becomes true (Filipowicz, 2011, pp. 172-174).

Moreover, it should also be pointed out that the reception of nationalists' arguments is also not facilitated by the fact that they usually make it quite clear to the opposing side of the discussion that only they are right, and this at the least hinders the discussion, if it does not end it altogether. While political liberals are also not free from this "sin", their situation is easier, because their conviction of their own exclusive righteousness, perceived as a kind of monopoly, is hidden behind the slogans on defending the individual, i.e. in principle, everyone (maybe with the exception of nationalists?). Therefore, liberals are sometimes also susceptible to exclusion, they reject those "maladapted" in their opinion, and do not even allow them the possibility to undergo a kind of "reeducation". Proponents and defenders of liberal democracy seem to live in fear of nationalists. These defenders, however, are not necessarily pure liberals. In this context, it is worth mentioning a category of Polish left-wing liberalism used by Zdzisław Krasnodębski (Krasnodębski, 2003, p. 273). In any case, this fear is sometimes felt so strongly, that they remove the word nation from the public debate, and label anyone who carelessly uses it, a nationalist. As it seems, in the opinion of political liberals, it is already dangerous that nationalism considers the nation to be of paramount value, and not every nation at that, because nationalists are concerned only with their own nation and not with others. Nationalism, with its proclivity for a dichotomous perception of the world, is therefore, in their opinion, a source of creation and exacerbation of divisions. They, therefore, consider it to be the opposite of peaceful coexistence. It seems, however, that such an approach is not entirely legitimate. If we take into account that in the history of mankind peace has been a rarity, if such peaceful moments may be indicated at all. It can be assumed that nationalism can, in certain situations, hinder peaceful coexistence at most, however, it must also be noted that peaceful coexistence of societies is more of a dream than a reality (and finally, nationalism is not as much the source of conflicts, as is often their tool).

Following this lead, it should be noted that nationalism seems to have two essential demands. The first demand is absolute loyalty from the group, and the second is the duty to maintain cultural specificity. Based on the anti-nationalist discourse, one would have to acknowledge the advantage of liberalism, which results from its openness. However, the point is 
that these two features apply also to the description of liberalism and it is not only because of their rather general character. While, as J. Gray noted, liberalism, whose aims are tolerance and pluralism in relation to the behaviour of individuals, in the sphere of its political demands is, however, an expression of intolerance. This is because it rejects the argument that various forms of government can, each in its own way, contribute to the achievement of genuine human wellbeing. Liberalism, according to J. Gray, rejected this argument because it undermined its claims as a political religion to a universal rule (and therefore the claims, which show the structural similarity of liberalism to evangelizing Christianity) (Gray, 2001b, p. 5).

Difficulties with the reception of nationalist thought from the standpoint of liberal democracy may also be considered a consequence of the progressive atomisation of society. The same point of reference may also be successfully used to explain nationalism's dislike for liberalism. However, it seems that this process of atomisation is rather inevitable. It is worth to recall in this context the opinion of P. Kaczorowski, who noted that the idea of democracy as a community, functions only in relation to its initial period. It comes from the uniqueness of the moment, in which the "universal sense of participation" is a consequence of the "revolutionary activity" that is necessary at a given moment. It is short-lived, however, because very quickly this goal of connecting "all" ceases to be visible and in its stead, conflicts of interest appear. This "new world" quite quickly "stops being a community of all and disintegrates into at least many different, particular communities", which, in turn, makes cooperation incomprehensible, and in many cases impossible, for people (Kaczorowski, 1998, pp. 11-12). It is a process of disintegration of community egoism into individual egoisms. Anyway, the requirement of social unity is generally quite problematic when faced with significant social diversity.

Another problem is related to the origin of nation states. As Marcin Król points out, they would not have arisen without the existence of "external pressure". However, if the origin of the nation state is not positive, but has a negative and reactive character, from the perspective of liberal democracy, the nation state can be "neither a particularly civilized, nor valuable creation". Nevertheless, it remains a fact (Król, 2004, p. 17). This is where the aforementioned tension appears. Nationalism, which means that certain groups of people may be required to have a sense of solidarity with regard to other groups (Weber, 2002, p. 667), leads directly to the recognition of "predominance" or at least "nonreplaceability" of cultural goods, which can only be preserved and developed by "cultivating its specificity". (Weber, 2002, p. 670). Meanwhile, the attention of 
atomized individuals in today's liberal democracy is directed primarily at consumption (although this does not seem to be a consequence of the pressure of political liberalism on these individuals, in the least), because it gives them the opportunity for fulfilment. Probably even when it remains only a desire, something unattainable. In the face of this preference, all other problems seem to be of little importance to these individuals. However, this should not prompt anyone to form a rather naïve demand, that it ought to be different. Consumption simply confirms the status of individuals, it is a motivator and often constitutes the meaning of their actions, and this is not likely to change. To put it a bit differently; the majority of the society is willing to deal with the dilemmas that everyday life brings them first, instead of debating political ideas which, in the face of everyday problems, must seem simply unimportant to them. One can simply say that the particular is always more important.

However, as José Ortega y Gasset writes, one may recall here the image of the mass-man described by him and list two of his traits: 1) uninhibited expansion of life's demands and needs in relation to oneself and 2) a strong lack of gratitude to those who made this comfortable life possible (Gasset, 2002, p. 60). Regardless of the adopted interpretation, the point is that firstly (even if it sounds grandiose), human life is not locked in the circle of consumption and possession, which quite strongly overshadow other fundamental, though immaterial aspects of human existence, including the presence of the community element, and what is more, are conditioned by them. Unfortunately, this veil is sometimes so tightly drawn that an individual may not even be aware of its existence. Secondly, the inability to satisfy the desires associated with material goods only exacerbates disintegration, and the atomized citizen easily succumbs to various pressures, including those of the state machinery. Perhaps it is precisely, as Piotr Nowak points out, that the modern state "penetrates the life of individuals, permeates them, controls and regulates", directing inward its political activity, consisting in the ability to distinguish the enemy from a friend (Nowak, 2008, p. 182). Therefore, is this one of the mechanisms that sustains the system called liberal democracy? Especially when one takes into account that the common good is more and more often a notion poorly adapted to reality, because, as Maria Jarosz observes, an extremely partydependent and ineffective state is more of an arena for conflicting group interests than for common interests and values (Jarosz, 2004, p. 23). The described situation can be explained as an outcome of the expansion of economic liberalism, which led to the marginalization of its political foundations. These two separate directions, as it might have seemed, at least up to a certain 
moment, merged or, to be precise, the latter was incorporated by the former. Moreover, they were strengthened by the dynamics of globalization processes, which led to the shaping of political relations based only and exclusively on effective dominance of the political sphere (Laska, 2006, p.8). To put it simply, transformation "omitted" the sphere of political awareness. As a result, not many people know what liberalism, the foundation of the new system, is (Olszewska-Dyoniziak, 2003, p. 96).

Even if the foregoing was untrue, the weakness of liberal democracy seems to include the very conviction that it is the best solution for the society. This criticism is by no means intended to undermine the validity of this statement, but only to show its weak point. If a value becomes so obvious that it is trivial, the drive to care for it disappears fairly quickly (J. S. Mill, 2002, p. 68). Then the imperative to constantly strive for such a value, to nurture it, usually disappears.

\section{The coherence conditions of the nationalist counter-project and its limitations}

If one assumes that nationalism is, generally speaking, an expression of dissatisfaction with the current political situation and the condition of society in such a system, it is worth noting that the propagation of nationalistic views requires from individuals a certain mobilisation, expressed through the possibility and ability to formulate assessments and the capacity for making choices, and thus also the rejection of certain values and (excluding pure negation) proposing other ones, considered to be better, instead. In order for such a critical reflection to emerge, there is undoubtedly a need for sensitivity, intellectual activity, reflection, critical thinking or at least a simple objection. After all, acceptance, or involuntary acceptance, has consequences for the individual, but it does not exert systemic pressure on the individual, because they are not treated by the system as dysfunctions.

The presence of the nationalistic paradigm in the public discourse is worth treating, most of all, as a voice in the dispute concerning the subjectivity and the obligations of an individual, society and state resulting from a particular concept. This might be a destructive force, but we cannot help noticing that this situation, in some aspects, seems quite beneficial for democracy itself. Although the dispute concerning fundamental issues puts axioms at risk, the ideas may have a new life through the necessity of confrontation. In the presence of a dispute, the depressing monotony may disappear, the monotony expressed in thoughtless reproduction of norms, which shows the taming of the will rather than its conscious activity. Questions may arise in return. 
Obviously, the situation may sometimes become uncontrollable, as sometimes the destruction in certain circumstances may turn out to be the simplest road and the simplest goal. Especially, as responsibility is in deficit, when the participants of the dispute are ready to lead it on various levels, having forgotten to define first what needs particular protection and what is the goal of their endeavors.

It is quite difficult for the nationalist discourse to break through as a sensible project into the public space. This is not only due to liberal criticism, or the criticism stemming from the freedom-related liberal foundations of a democratic state. The problem with nationalism is that nationalists themselves often consider members of their society to be quite "unruly". However, this dominant view that nationalism should only be seen as a threat to liberal democracy, effectively draws people's attention away from its structural problems and actual threats, which nationalism and nationalists are unlikely to be the source of.

M. Król points it out in his writing, that the persisting "anti-nationalistic nature of political correctness" leads to the fact that "the true face of possible contemporary nationalism, which develops freely and enjoys power, is simply unknown to us" (Król, 2004, pp. 56-57). In Poland, nationalism has not yet had the opportunity to materialise its ideas, although it should be added that nationalism has nowadays become more visible (manifested) in the public space.

In order to determine the conditions of coherence of the nationalist counter-project and its limitations, it is worth to refer to the ideas of R. Dmowski and to discuss the elements related to the analyzed issue. R. Dmowski described the national interest as a moral relationship with the nation, independent of the individual's will (Dmowski, 1907, pp. 235). At the same pointing out that a given nation, in order to become a nation, first had to have a state, because a state by its very existence produces a nation (Dmowski, 1907, p. 250). Thus, if the nation did not break the moral connection with the state tradition, if it did not lose its national interest, it would not lose both the conscious and, as it were, intuitive (spontaneous) aspiration to regain its politically independent being (Dmowski, 1907, p. 251). According to R. Dmowski, in a certain sphere of actions, an individual connected through past generations to its nation, has no free will, but must obey the collective will of the nation, i.e. the will of all of its past generations, understood as inherited, relatively stable instincts (Dmowski, 1907, pp. 235-236). This moral sanction, i.e. national ethics, as he wrote, determines the direction and scope of conduct in national matters (Dmowski, 1907, p. 237). However, R. Dmowski did not really mean the far-reaching limitations of the individual. 
As it seems, he only assumed that the social being was based on a fairly rational reflection, arising in the process of participation, that individuals, in order to maintain its duration, should sacrifice a part of their personal interests (Dmowski, 1907, p. 175). At the same time, as a negative example, he pointed to politically passive societies, which usually leave it to a small handful of people to direct the fate of the country, and then they blame them for failures (Dmowski, 1907, p. 197). At the same time, however, he stipulated that it was not a matter of every citizen being a politician (Dmowski, 1907, p. 220). By this civic duty he understood primarily, that citizens should be in tune with the condition and the elementary needs of the country (Dmowski, 1907, p. 220).

While comparing the nations of Western Europe with the Polish nation, he noticed that both the spiritual resources (that instinct), as well as the material resources of the Polish nation inherited from previous generations, due to the fact that the Poles are a younger nation, which lags behind civilization-wise, are much more modest (Dmowski, 1936, p. 31). Therefore, he probably did not attribute the ability to properly recognize the national interest to all members of the Polish nation, recognizing that national ethics also allows us to oppose the contemporary generation, if this generation fails to perform the national duties. It also allows us to destroy the prosperity, peace and happiness of the present generation in certain situations, where sacrificing them is necessary to maintain the continuity of the national being. He also pointed out, that this ethic does not oblige us to think in the same way as our ancestors did, but to think and act as it is necessary in the given conditions for the preservation and development of the national being (Dmowski, 1907, p. 237; 1925, p. 10). Admittedly, one may assume that in the times when R. Dmowski formed his thoughts, under a foreign yoke, it was much more difficult to "become a nation" and the sense of responsibility for Poland was often "extinguished" (Konopczyński, 1989, p. 19). However, there is no doubt that the national interest, within the meaning which R. Dmowski ascribed to it, is not tantamount to a consent to what the majority currently thinks about it (Walicki, 2000, p. 263).

It should also be pointed out, that democracy as the National Democrats understood it, did not mean striving for formal equality among atomized individuals, but was first and foremost a tool, whose function was to sensitize individuals to the problems of the nation and their citizenship (Grott, 2004, p. 426). The disappearance of national loyalty, as W. Wasiutyński argues, leads to the annihilation of the nation. In the situation of a conflict of loyalty, especially in the case of external oppression, a nation without national loyalty (if it is still possible to speak of a nation in such a case) becomes defenceless (cf. Wasiutyński, 1961, p. 25). R. Dmowski wrote that in such 
a situation, human communities become inert, anarchic masses, which are no longer bound by a moral coercion, but by a physical one (Dmowski, 1907, p. 241).

It is worth mentioning here the specific origin of nation states, which would probably not have emerged if there had not been an external pressure (Król, 2004, p. 17). It seems, therefore, that National Democracy, similarly to nationalists in other underdeveloped countries, was doomed to chauvinism, xenophobia and anti-Semitism. In M. Król's assessment, anti-Semitism, which could be regarded as an unnecessary addition to otherwise fairly reasonable nation-forming requirements, is not an unnecessary addition or a negative fantasy after all, because it "creates a form of expression and a type of social bond, absolutely necessary for the national project". When one wants to achieve transformations, one simply has to build from what is available. This is the structure of nationalist thinking, also of the contemporary kind, although today it is hidden behind the veil of political correctness (Król, 2004, pp. 31-32). However, it is worth to reiterate the concept of Bogumił Grott, that the concept of a nation state, i.e. a state of a given nation (the ruling nation), as opposed to a state of all citizens living within its borders, a concept with its own antidemocratic and anti-liberal "blade" is rather invisible today, but the focus of political discussion is shifted toward the fact of the existence of a nation (Grott, 2004, p. 435).

As J. Gray argues, there are no criteria of legitimacy of political systems, which would apply in all historical contexts. Although some forms of good and evil are typically human, the historical conditions which people live in are too complex and changeable to translate universal values into a universal theory of political legitimacy (Gray, 2001a, p. 171). J. Gray also points out that today's systems, which are considered legitimate, include: the rule of law, effective representative institutions, authorities removable by citizens without the need to resort to violence, the ability to satisfy the basic needs of all and the ability to protect minorities from discrimination, but be also recognizes that apart from fulfilling these conditions, they must also reflect the ways of their citizens' lives and their identities (Gray, 2001a, p. 171). May a nation "fetter" individuals, then? Undoubtedly, nationalism was a system of legitimate authority, which filled a certain void at a certain historical moment (Crick, 2004, p. 107). But why should people still think that, for example, an island, a plain or a valley should necessarily constitute a nation state (Crick, 2004, p. 109)? B. Crick does not contradict or deny such a sense of national belonging. However, he sees a danger in deriving the national feeling from objective and rational criteria. He does not reject it, as long as it is a matter of will and consciousness (Crick, 2004, p. 109) and as long as the national 
feeling recognises the equality of the national freedom and political freedom (Crick, 2004, p. 122). and does not concern mainly nationalism.

Pluralism probably has its "limits", drawn each time by the tradition "shared" in a given society (Krasnodębski, 2003, p. 152). Whereas this problem did not exist in traditional societies, possessing the unchanged, fixed canon of values with the obligation to implement them without the need to justify them, as well as the sanctions included in mechanisms of socialization and social control, contemporary Western societies, characterized with wide social and cultural pluralism on all levels of life, this problem is becoming particularly noticeable (Budzyńska, 2008, pp. 36-37), since all attempts at shaping collective identity and awareness are often perceived as one of forms of oppression and compulsion.

\section{Conclusion}

The starting point for the analyses conducted in this article was the thesis that liberal democracy is in crisis. It should be pointed out that liberal democracy is a model solution. Its attractiveness is attributed to the extremely vast sphere of freedom offered to individuals or, to be more precise, to each of these individuals. As the author demonstrated, the essence of liberal democracy lies in the combination of the idea of equality and freedom, which consists in the statement that the requirement for freedom is equality in law. In the light of the conducted analyses it is worth considering, however, whether the above relationship has not been reversed, so that through freedom each individual gains the feeling of equality with other individuals. A small difference, it might seem, but is we assume that it is possible to direct effectively freedom of choice into some insignificant, façade areas, a serious problem emerges here. The belief in equality obtained in this way would probably turn out to be delusion. It should be observed here, however, that this issue was not analyzed in detail in this paper.

Another issue is the attachment of liberal democracy to formal rules. They help define its conformity - legal validity, but to a rather limited extent, since, as it seems, liberal democracy is pleased with the quantitative diagnosis rather that qualitative one. In this context the problem of election absenteeism of individuals was signaled.

The author also points at the marginalization of political liberalism to the advantage of economic liberalism. The symptoms of this preference were found in the atomization of the society, heightened, inter alia, by consumerism which for them is becoming the only - closed 
world, which, in turn, leads to the withdrawal of individuals from the public sphere and their involuntary resignation from, for example, the controlling rights they have over the authority. The pessimistic vision of liberal democracy is completed with the description of the possibilities offered by the instruments possessed by those in power, who can model and control in an invisible way such "seduced" individuals. Nevertheless, liberal democracy as a social system still seems to have some attributes that make it incredibly attractive. The problem seems to lie in the lack of political insight shown by system members. The reduction of the political sphere in liberal democracy to the absolute minimum led to the situation in which it is considered unnecessary to prepare to participate in this system. Liberal democracy thus become exclusive but at the same time it eludes any form of control.

Perhaps, as Karl Raimund Popper noted, the issue of freedom carries with it a naive and, at the same time, dangerous belief that by removing all forms of oppression and all other obstacles, it must inevitably lead to an unrestricted rule of truth and law (Popper, 1997, p. 177).Perhaps this is why any counter-project to liberal democracy causes concerns and is presented as a threat to the freedom of individuals, even when the individuals living in a liberal democracy are experiencing significant deficits in the area of this freedom. It is worth noting at this point, that nationalism is not the only threat to the freedom of individuals, given that a liberal democratic state, which has a monopoly on coercion, forces citizens every day, often in a subtle, imperceptible way, to do many incomprehensible things, which even sensible people are ultimately willing to do. The threat to the apparently sanctioning power of rational and objective criteria, however, seems to be a much wider problem.

As far as the nationalist counter-project is concerned, it should be noticed, first of all, that it operates only on the level of ideas. As there is no practical experience in the implementation of these ideas, it can only remain a set of postulates. Therefore we cannot answer whether and how they would work in practice and what evolution they would undergo. The comparison between the nationalist concept and the liberal democracy practice is impossible due to this incompatibility of levels. While the liberal democracy practice seems, out of its certain helplessness, to tolerate civic unpreparedness and passivity, it should be noticed that in the model concept, civic awareness in liberal democracy is presented as the foundation of individuals' security. As for nationalism, it rejects the policy of passivity, but this does not mean that nationalism prefers free, unhindered will. It is an individual's obligation to obey the collective will of the nation (specific loyalty), while 
the category of collective will of the nation or national interest does not belong to democratic standards as it is not determined by the majority. In nationalism, the tendency to exclude is manifested through such preference for unity. Thus specific citizenship from the nationalist point of view, taking into account the fact that the state generates the nation, would have to lead towards reduction of pluralism in the society.

Nationalism, as indicated above, is only one of many proposals for organizing the social life. The fundamental problem, however, boils down to the issues of free will and conscience which are able to resist the power of rationality which reduces all doubts. But if this is so, then we need to regain the human being first (see Żyro, 2008, pp. 532-533). However, this quite simply defined goal may encounter quite serious difficulties when we try to accomplish it. It is by no means clear how we could regain the human being. If we assume that we shall regain human beings through specific awakening, a question arises here concerning not critical conditions which must appear for the change to take place, but concerning the direction of this potential change. Such direction is by no means obvious. If, on the other hand, we treat regaining as conscious activity, here we enter the tricky area of social engineering. And here the threat of oppressiveness looms.

However, perhaps we are essentially still dealing with the process of "conquering" (cf. Staniszkis, 2012, pp. 9-10). If so, the pressure of the state, the pressure of authority, is inevitable. It does not have an alternative in a situation, where politics is always perceived as a way of using the accumulated power, gaining more power and reducing the power of opponents. In such an approach, politics is only about techniques and mechanisms, not goals, values and ideals (cf. Król, 1989 , p. 89). In such case, politics is only a struggle for authority, influence and opportunities to pursue particular interests. Perhaps ideals seem to be a necessary condition for political activity only for observers and novices, while this, in their opinion, highly important, essential perspective is, in fact, only a consequence of misunderstanding reality. But it might be that such evaluation only confirms the influence of the overwhelming power of monopoly. It might be, after all, that how we perceive the world and also how we would like to arrange it - is (only and at the same time as much as) the emanation of our existential situation, our experiences, our needs and related expectations. If this is so, then some possibilities of reducing the tension caused by the abovementioned "conquering" and related incompatibility should be sought in the pluralism of the public discourse. Taking it out of the control of the authority. Maybe the implementation of the public 
discourse as a space in which various ideas and views are confronted, may turn out to be the basic requirement for the rebirth of a human being and human community.

\section{References}

1. BASZKIEWICZ, J.(2002) Powszechna historia ustrojów państwowych. Gdańsk: Arche.

2. BUDZYŃSKA, E. (2008) Podzielane czy dzielące? Wartości społeczeństwa polskiego. In: J. MARIAŃSKI, L. SMYCZEK (eds.). Wartości, postawy $i$ więzi moralne w zmieniajacym się społeczeństwie. Kraków: Wydawnictwo WAM, pp. 35-56.

3. CRICK, B. (2004) $W$ obronie polityki. Trans. by A. Waśkiewicz. Warszawa: Wydawnictwo Naukowe PWN.

4. CYWIŃSKI, B. (1985) Doświadczenie polskie. Warszawa: Pokolenie.

5. DMOWSKI, R. (1907) Myśli nowoczesnego Polaka. Lwów: Nakładem Towarzystwa Wydawniczego. H. Altenberg. E. Wende i Spółka.

6. DMOWSKI, R. (1925) Nasz program. In: Nasz program. Przemówienia R. Dmowskiego, prof. R. Rybarskiego i pos. St. Kozickiego na Konferencji Krajowej Zwiazku Lud.-Nar. W Warszawie, dn.18. X 1925 r. Warszawa: Nakładem Związku Lud.-Nar., pp. 5-12.

7. DMOWSKI, R. (1936) Kościól, naród i państwo. Pelpin: Nakładem i czcionkami Drukarni i Księgarni.

8. ETZIONI-HALEVY, E. (2005) Władza w demokracji: teoria elit demokratycznych. In: P. ŚPIEWAK (ed.), Przyszłość demokracji. Wybór tekstów. Trans. by P. Rymarczyk, Warszawa: Fundacja Aletheia, pp. 107-132.

9. FILIPOWICZ, S. (2011) Prawda $i$ wola złudzenia, Warszawa: Wydawnictwa Akademickie Oficyna Wydawnicza Łośgraf - Wiesław Łoś.

10. GASSET, J. O. (2002) Bunt mas. Trans. by P. Niklewicz. Warszawa: Warszawskie Wydawnictwo Literackie Muza.

11. GRAY, J. (2001a) Dwie twarze liberalizmu. Trans. by P. Rymarczyk. Warszawa: Fundacja Aletheia.

12. GRAY, J. (2001b) Postscriptum: po liberalizmie. In: J. GRAY, Po liberalizmie. Eseje wybrane. Trans. by P. Maciejko, P. Rymarczyk. Warszawa: Fundacja Aletheia, pp. 5-50. 
13. GROTT, B. (2004) Obóz narodowy wobec demokracji i liberalizmu. In: W. KAUTE (ed.), Demokracja, liberalizm, spoleczeństwo obywatelskie. Doktryna $i$ myśl polityczna. Katowice: Wydawnictwo Uniwersytetu Śląskiego, pp. 424-435.

14. GROTT, B. (2014) Dylematy polskiego nacjonalizmu. Powrót do tradycji czy przebudowa narodowego ducha. Radzymin: Wydawnictwo von Borowiecky, Klub ZachowawczoMonarchistyczny.

15. JAROSZ, M. (2004) Władza. Przywileje. Korupcja. Warszawa: Wydawnictwo Naukowe PWN.

16. KACZOROWSKI, P. (1998) My i oni. Państwo jako jedność polityczna. Filozofia polityczna Carla Schmitta $w$ okresie republiki weimarskiej. Warszawa: Oficyna Wydawnicza Szkoły Głównej Handlowej.

17. KACZOROWSKI, P. (2005) Państwo w czasach demokracji. Warszawa: Instytut Studiów Politycznych Polskiej Akademii Nauk.

18. KARPIŃSKI, A. (2001) Aktualne i możliwe treści demokracji współczesnej. In: P. W. JUCHACZ, R. KOZŁOWSKI (eds.), Filozofia a demokracja. Poznań: Wydawnictwo Naukowe Instytutu Filozofii Uniwersytetu im. Adama Mickiewicza w Poznaniu, pp. 241250.

19. KELSEN, H. (1936) O istocie $i$ wartości demokracji. Trans. by F. Turynowa. Warszawa: Księgarnia Powszechna.

20. KŁOSKOWSKA, A. (1997) Skąd i po co naród? Znak, 3, pp. 69-78.

21. KOŁAKOWSKI, L. (1999) Demokracja jest przeciwna naturze. In: E. NOWICKA, M. CHAŁUBIŃSKI (eds.), Idee a urządzanie świata spotecznego. Księga jubileuszowa dla Jerzego Szackiego. Warszawa: Wydawnictwo Naukowe PWN, pp. 72-76.

22. KONOPCZYŃSKI, W. (1989) O miejsce dla Dmowskiego w historii. In K. Niklewicz (ed.), Roman Dmowski 1864-1939. W pięćdziesięciolecie śmierci. Londyn: Instytut Romana Dmowskiego, pp. 18-21.

23. KRASODĘBSKI, Z. (2003) Demokracja peryferii. Gdańsk: Wydawnictwo słowo/obraz terytoria.

24. KRÓL, M. (1989) Stownik demokracji. Kraków: Społeczny Instytut Wydawniczy Znak.

25. KRÓL, M. (2004) Patriotyzm przyszlości. Warszawa: Rosner i Wspólnicy. 
26. KURCZEWSKA, J. (1988) Etnocentryzm a ideologia narodowa. Kultura i Społeczeństwo, 4, pp. 65-87.

27. KWAŚNIEWSKI, K. (1996) O nacjonalizmie inaczej. Sprawy Narodowościowe - Seria nowa, 1, pp. 59-82.

28. LASKA, A. (2006) Ideotwórczy wymiar dyskursu politycznego w demokracji deliberatywnej. In: R. BÄCKER, J. MARSZAŁEK-KAWA (eds.). Między otwarta a domknięta myśla polityczną. Szkice o najnowszej refleksji politycznej. Toruń: Wydawnictwo Mado, pp. 7-17.

29. MAJCHROWSKI, J. M. (1986) Szkice z historii polskiej prawicy politycznej lat drugiej Rzeczypospolitej. Kraków: Uniwersytet Jagielloński.

30. MILL, J. S. (2002) O wolności. Trans. by A. Kurlandzka. Warszawa: Wydawnictwo Akme.

31. MURAWSKI, K. (1993) Filozofia polityki. Wybrane zagadnienia prakseologiczne. Warszawa: Wydawnictwo Instytutu Filozofii i Socjologii PAN.

32. NOWAK, P. (2008) Posłowie. In: C. SCHMITT. Lewiatan w teorii państwa Thomasa Hobbesa. Sens i niepowodzenie politycznego symbolu. Trans. by M. Falkowski. Warszawa: Prószyński i S-ka, pp. 157-182.

33. OLSZEWSKA-DYONIZIAK, B. (2003) Człowiek a wspólnota. Antropologiczne aspekty w doktrynach politycznych. Wrocław: „Atla 2”.

34. POPPER, K. R. (1997) W poszukiwaniu lepszego świata. Wykłady i rozprawy z trzydziestu lat. Trans. by A. Malinowski. Warszawa: Książka i Wiedza.

35. RADZIK, R. (1997) Co to jest naród? Znak, 3, pp. 79-91.

36. RUDNICKI, Sz. (1985) Obóz Narodowo-Radykalny. Geneza i działalność. Warszawa: Czytelnik.

37. RYSZKA, F. (1984) Nauka o polityce. Rozważania metodologiczne. Warszawa: Państwowe Wydawnictwo Naukowe.

38. STANISZKIS, J. (2012) Zawładnacć! Zarys procesualnej teorii władzy. Warszawa: Wydawnictwo Naukowe Scholar.

39. STUDNICKI, W. (2001) Ludzie, idee i czyny. J. GZELLA (ed.). Toruń: Wydawnictwo Adam Marszałek.

40. SZACKI, J. (1991) Ideologia. In: J. SZACKI, Dylematy historiografii idei oraz inne szkice i studia. Warszawa: Wydawnictwo Naukowe PWN, pp. 218-237. 
41. SZACKI, J. (1994) Liberalizm po komunizmie. Kraków: Społeczny Instytut Wydawniczy Znak. Fundacja im. Stefana Batorego.

42. TALMON, J. L. (1992) O demokracji totalitarnej. Trans. by W. Buchner. Znak, 4, pp. 6780 .

43. TOMASIEWICZ, J. (2003) Ugrupowania neoendeckie w III Rzeczypospolitej. Toruń: Wydawnictwo Adam Marszałek.

44. WALICKI, A. (2000) Trzy patriotyzmy. In: A. WALICKI, Polskie zmagania z wolnością. Widziane z boku. Kraków: Universitas, pp. 225-270.

45. WAPIŃSKI, R. (1980) Narodowa Demokracja 1893-1939. Ze studiów nad dziejami myśli nacjonalistycznej. Wrocław: Zakład Narodowy im. Ossolińskich - Wydawnictwo.

46. WAPIŃSKI, R. (1989) Roman Dmowski. Lublin: Wydawnictwo Lubelskie.

47. WASIUTYŃSKI, W. (1961) Libido i lojalność w polityce. Londyn: Nakładem "Myśli Polskiej".

48. WASIUTYŃSKI, W. (1986) O program większości. Londyn: Odnowa.

49. WEBER, M. (2002) Gospodarka i społeczeństwo. Zarys socjologii rozumiejacej. Trans. by D. Lachowska. Warszawa: Wydawnictwo Naukowe PWN.

50. ŻYRO, T. (2004) Wstęp do politologii. Warszawa: Wydawnictwo Naukowe PWN.

51. ŻYRO, T. (2008) Wola polityczna. Siedem prób z filozofii politycznej. Warszawa: Wydawnictwa Akademickie i Profesjonalne.

52. ŻYRO, T. (2013) Reprezentacja polityczna w trójkącie niemożności: ochlokracja, biurokracja, cezaryzm. In: T. ŻYRO (ed.), Reprezentacja polityczna. Warszawa: Wydział Dziennikarstwa i Nauk Politycznych. Uniwersytet Warszawski, pp. 59-92. 